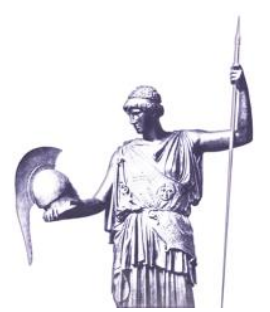

Connections: The Quarterly Journal

ISSN 1812-1098, e-ISSN 1812-2973

Джеймс Уизер, Connections QJ 15, № 2 (2016): 84-100

https://doi.org/10.11610/Connections.rus.15.2.06

Рецензированная статья

\title{
Смысл гибридной войны
}

\section{Джеймс К. Уизер}

Европейский центр исследований по вопросам безопасности им. Джорджа К. Маршалла, http://www.marshallcenter.org

Резюме: Термин «гибридная война» стал объектом пространного анализа со стороны теоретиков, должностных лиц, определяющих политику и наблюдателей после того, как Россия оккупировала Крым в марте 2014 года. Эта тема перестала быть предметом изучения только со стороны военных стратегов, и вошла в более широкую политическую область в качества существенного для Запада вызова безопасности. В этой статье сделана попытка поместить спор о гибридной войне в более широкий аналитический и исторический контекст и обобщить дискуссии, касающиеся этой концепции и связанные с ней стратегическими концепциями. Конкретным фокусом дискуссии является российский подход к гибридной войне, продемонстрированный в операциях на Украине.

Ключевые слова: война, стратегия, Российская Федерация, НАТО, европейская безопасность.

\section{Введение}

С марта 2014 года, когда Российская Федерация оккупировала Крым, анализы и комментарии по вопросам гибридной войны начали расти в экспоненциальном порядке. ${ }^{1}$ Поиск в Интернете дает сотни публикаций, касаю-

1 В число последних анализов входят: Frank Hoffman, "On Not-So-New Warfare: Political Warfare vs. Hybrid Threats," War on the Rocks (blog), 28 July 2014, http://warontherocks.com/2014/07/on-not-so-new-warfare-political-warfare-vs-

hybrid-threats (по состоянию на 8 декабря 2015); Max Boot, "Countering Hybrid Warfare," in Armed Conflict Survey 2015, ed. Nigel Inkster (London: IISS, 2015); Ralph D. Thiele, "Crisis in Ukraine - The Emergence of Hybrid Warfare," ISPSW Strategy Series, May 2015; Rod Thornton, "The Changing Nature of Modern Warfare," RUSI Journal 160:4 (2015): 40-48; Lawrence Freedman, "Ukraine and the Art of Limited 
щихся этого явления. Гибридная война стала наиболее общим термином для исследования и обобщения сложности войны двадцать первого века, подразумевающий множественность акторов и размывание традиционных отличий между разными типами вооруженных конфликтов и даже между войной и миром. Гибридная война перестала быть темой, интересной только военным стратегам, поскольку она вошла в более широкую публичную сферу и стала для западных государств основной заботой, связанной с безопасностью. И НАТО, и Европейский Союз разрабатывают стратегии укрепления оборонных способностей и предотвращения гибридных нападений.

В этой статье сделана попытка уточнить разное содержание, которое вкладывают в понятие гибридной войны и в связанные с ней термины теоретики и политические аналитики, и обобщить результаты дискуссий по этой теме к данному моменту. В работе рассматривается, в частности, российский подход к гибридной войне, продемонстрированный в операциях на Украине, и оценивается вкратце значение такого развития событий для западной политики безопасности.

\section{Определение гибридной войны}

Не удивительно, что существует множество определений гибридной войны. Эта концепция подвергалась описанию разными, хотя и связанными, способами, причем все эти определения формировались в очень короткий период времени. Дефинирование гибридной войны не есть всего лишь академическое занятие. То, как определено это понятие, может определить, как государства воспринимают и как реагируют на гибридные угрозы, а также, какие государственные ведомства принимают участие в противодействие им.

Один из подходов к гибридной войне основывается на исторической перспективе. В этом случае термин гибридная война определяется как просто параллельное использование конвенциональных и нерегулярных сил в одной и той же военной кампании. Военный историк Петер Р. Мансоор, к примеру, определяет гибридную войну как «конфликт, подразумевающий сочетание конвенциональных военных сил и нерегулярных сил (партизан, повстанцев и террористов), которые могут быть государственными или негосударственными акторами, действующими во имя достижения общей политической цели». ${ }^{2}$ С этой точки зрения, гибридная война очевидно не является чем-то новым. Есть множество примеров гибридной техники и ги-

War," Survival 56:6 (2014): 7-38; Michael Kofman and Matthew Rojansky, "Kennan Cable No. 7: A Closer Look at Russia's Hybrid War," Wilson Center, 14 April 2015, www.wilsoncenter.org/publication/kennan-cable-no7-closer-look-russias-hybrid-war (по состоянию на 8 декабря 2015).

2 Peter R. Mansoor, "Hybrid War in History," in Hybrid Warfare: Fighting Complex Opponents from the Ancient World to the Present, ed. Williamson Murray and Peter R. Mansoor (Cambridge: Cambridge University Press, 2012), 2. 
бридного подхода на тактическом, оперативном и стратегическом уровне, уходящих далеко в прошлое до времен Пелопонесской войны и работ китайского философа Сунь Цзы, жившего в пятом веке до новой эры. Нерегулярные бойцы доказали, что могут стать проклятием для многочисленных конвенциональных вооруженных сил. Такие огромные армии, как Великая армия Наполеона и Вермахт Гитлера с трудом боролись с нерегулярными бойцами, которые понимали и использовали местный человеческий и географический ландшафт и нападали на уязвимые базы снабжения и линии коммуникаций. Со временем партизанские операции начинали оказывать существенное и устойчивое влияние на более широкие конвенциональные военные кампании, частью которых они являлись. Недавние антиповстанческие кампании в Ираке и Афганистане еще раз показали, насколько трудно победить убежденных нерегулярных бойцов без нарушения человеческих прав местного населения, тем самым подрывая внутреннюю и международную общественную поддержку кампании.

В 2000-х использование термина «гибридная» стало обычным способом описания современной войны, в частности, и из-за увеличивающейся изощренности и смертоносности негосударственных акторов, использующих насилие, и растущего потенциала кибер-войны. Хотя не было общего согласия, что это обязательно является новой формой войны, ${ }^{3}$ в определениях гибридной войны подчеркивалось слияние конвенциональных и нерегулярных подходов во всем спектре конфликтов. К примеру, в 2007 году Фрэнк Г. Хоффман, ведущий комментатор этой концепции, дефинировал гибридную войну как "Угрозы, которые включают полный спектр разных способов ведения военных действий, в том числе использование конвенциональных способностей, использование тактики нерегулярных сил, террористические действия с применением недискриминирующего насилия и принуждения, беспорядки, инициированные преступными элементами, применяемые обеими сторонами и разными негосударственными игроками». ${ }^{4}$ Во время войны с Грузией в 2008 году Россия, к примеру, использовала сочетание регулярных вооруженных сил, южноосетинских и абхазских милиций и российских сил особого назначения (СОH), действующих под прикрытием образа сил «местной обороны». Считается, что такие гибридные войны отличает от их форм в прошлом комбинирование конвенциональных и нерегулярных методов войны. В прошлом, конвенциональные и нерегулярные операции проводились параллельно, но отдельно друг от друга, а не интегрированным образом, как сейчас. Кроме того, операции, проводимые нерегулярными бойцами, обычно были вспомогательными для кампаний конвенциональных вооруженных сил.

3 U.S. Government Accountability Office (GAO), Hybrid Warfare, GAO-10-136R (Washington, DC: GAO, 2010), доступно на http://www.gao.gov/products/GAO-101036R (по состоянию на 4 декабря 2015).

4 Frank G. Hoffman, Conflict in the $21^{\text {st }}$ Century: The Rise of Hybrid Wars (Arlington, VA: Potomac Institute for Policy Studies, 2007), 8. 
До 2014 года наиболее часто приводимым примером военных действий, соответствующих современным дефинициям гибридной войны, был конфликт между Израилем и «Хезболла». «Хезболла», получающая подготовку и оборудование от Ирана, стала неожиданностью для Израиля изощренным сочетанием партизанской и конвенциональной военной тактики и использованием вооружения и коммуникационных систем, ассоциируемых с вооруженными силами развитых стран. На стратегическом уровне «Хезболла» эффективно использует Интернет и другие медиа для информации и пропаганды. Ее информационный менеджмент с самого начала конфликта оказался гораздо более успешным в оказании влияния на мировое мнение, чем менеджмент Израиля. Как показывает приведенная выше дискуссия, гибридное сочетание конвенциональных и нерегулярных методов войны применялось в течение всей человеческой истории. Но пример «Хезболла» и другие примеры, в том числе партизаны в Чечне и в последнее время Исламское государство (ИГ), демонстрирует, что современные оружейные системы существенно повысили смертоносность негосударственных акторов. Развитие информационных технологий также дало этим группам беспрецедентную возможность принимать участие в информационной войне и эффективно конкурировать с государством при формировании общественного мнения. Обзор обороны США от 2010 года, охватывающий четырехлетний период, подтвердил эти изменения, дав определение гибридной войны следующим образом: «сегодняшние гибридные подходы могут касаться противников, являющихся государствами, которые используют расширенные формы войны, возможно, используют прокси-силы для принуждения или запугивания, или негосударственных акторов, которые применяют оперативные концепции и высокотехнологические способности, обычно ассоциируемые с государством». ${ }^{5}$

\section{Гибридная война после 2014 года}

Как было отмечено выше, действия России на Украине в 2014 году повысили интерес к концепции гибридной войны. Для многих западных комментаторов, по-видимому, слово «гибридная» оказалось наиболее подходящим для описания разнообразия и сочетания инструментов и методов, примененных Российской Федерацией во время аннексии Крыма и поддержки сепаратистских групп на Восточной Украине. В число российских методов входили традиционное сочетание конвенциональных и нерегулярных боевых операций, но также и поддержка и покровительство политических протестов, экономическое принуждение, кибер-операции и, в частности, интенсивная дезинформационная кампания. В одном интервью от июля 2014 года бывший генеральный секретарь НАТО, Андерс Фог

5 Department of Defense, Quadrennial Defense Review Report (Washington, DC: Department of Defense, 2010), 8, http://www.defense.gov/Portals/1/features/defense Reviews/QDR/QDR_as_of_29JAN10_1600.pdf (по состоянию на 4 декабря 2015). 
Расмуссен, обрисовал российскую тактику как «гибридную войну», которую он определил, как «сочетание военных действий, тайных операций и агрессивной программы дезинформации». ${ }^{6}$ Издание 2015 года Военного баланса дает комплексную дефиницию последних проявлений гибридной войны, ставя ударение на применяемые методы, а именно «использование военных и невоенных средств в интегрированной кампании, направленной на достижение эффекта неожиданности, захвата инициативы и достижения психологического и физического превосходства с использованием дипломатических средств; изощренных и быстрых информационных, электронных и кибер операций; тайных, а иногда и явных военных и разведывательных действий; и экономического давления». ${ }^{7}$

То, что отличает это определение от рассматриваемых выше, это ударение на невоенные методы конфликта и, в частности, на информационную войну. Использование направленных на оказание давления информационных операций является наиболее отличительной чертой последних описаний гибридной войны, и оно позволяет провести некоторые сравнения между кампаниями ИГ на Ближнем Востоке и очень отличающейся войны и отличающегося театра военных действий на Украине. ИГ эффективно сочетало конвенциональную, партизанскую тактику и жестокие акты терроризма, но оно так же использовало пропаганду и информационную войну в беспрецедентной для негосударственного актора степени. Продуманные кампании в социальных медиа прославляли его цели, а высококачественная визуальная пропаганда помогала группировке рекрутировать тысячи иностранных боевиков в свои ряды. Информационная война также занимала центральное место в успешной российской кампании в Крыму в 2014 году. На тактическом уровне, электронная война (ЭВ) и кибер-атаки нейтрализовали способность украинских властей реагировать, тогда как широкое применение технологий использования СМИ размывало грань между правдой и ложью, создавая альтернативную реальность для тех из наблюдателей, которые принимали точку зрения на события российских СМИ. Стратегическая информационная кампания России на Украине основывалась на использовании существующих социальных уязвимостей, ослабленного управления и государственных институций и на подрыве восприятия легитимности украинского государства. Как и ИГ, Россия использовала информационные операции для оказания влияния и для формирования общественных восприятий, еще одно подтверждение факта, что последнее стало стратегическим центром тяжести в современных вооруженных конфликтах.

6 Mark Landler and Michael R. Gordon, "NATO Chief Warns of Duplicity by Putin on Ukraine," The New York Times, 8 July 2014, www.nytimes.com/2014/07/09/world/ europe/nato-chief-warns-of-duplicity-by-putin-on-ukraine.html (по состоянию на 7 декабря 2015).

7 "Complex Crises Call for Adaptable and Durable Capabilities," The Military Balance 115:1 (2015): 5 . 
Вряд ли является неожиданностью то, что российские аналитики утверждали, что информационная и психологическая война есть основа победы в так называемой «войне нового поколения». ${ }^{8}$ В недавнем докладе Центра квалификации по стратегическим коммуникациям (СТРАТКОМ) НАТО о российской информационной войне на Украине сделаны схожие заключения, касающиеся значения "информационного превосходства» для успеха России, ${ }^{9}$ а главнокомандующий союзных сил НАТО в Европе (ГССЕ), генерал Филип Бридлав, отразил оцепенение, охватившее многих западных руководителей, описав российскую кампанию как «наиболее удивительный информационный блицкриг, который когда-либо мы видели в истории информационной войны». ${ }^{10}$ По мнению бывшего российского телевизионного продюсера Петра Померанцева, этот «Блицкриг» идет гораздо дальше, чем традиционные операции информационной войны. Он утверждает, что «Новая Россия не просто занимается мелкой дезинформацией, подлогами, враньем, утечками и кибер-саботажем, обычно ассоциируемыми с информационной войной. Она заново изобретает реальность». ${ }^{11}$

\section{Касающиеся данной темы теории современной войны}

Возможно, концепция гибридной войны мало что добавляет к идее асимметричной войны. Этот термин, получивший популярность после окончания Холодной войны, должен характеризовать виды стратегий и тактик, используемых государствами и негосударственными субъектами, являющимися оппонентами США и их союзников для противодействия полному технологическому и военному превосходству Запада. Эти несимметричные методы могут естественно сдвигаться в невоенную область, расширяя серую зону между войной и миром, которая и была использована Россией на Украине. Однако, так называемые асимметричные методы войны, по существу противопоставляющие силу одного против слабостей другого, всегда были присущи успешным военным стратегиям. Многие из элементов гибридной войны являются предметом дискуссий о «войне четвертого поко-

8 К примеру, смотри Sergei G. Chekinov and Sergei A. Bogdanov, "The Nature and Content of New Generation War," Voyenna Mysl (Military Thought) 4 (2013): 12-23, http://www.eastviewpress.com/Files/MT_from\%20the\%20current\%20issue_No.4_20 13.pdf (по состоянию на 9 декабря 2015).

9 NATO Strategic Communications Center of Excellence (StratCom COE), Analysis of Russia's Information Campaign Against Ukraine (Riga: NATO StratCom COE, 2014), 4, http://issuu.com/natostratcomcoe/docs/ukraine_research_natostratcomcoe_02 (по состоянию на 15 декабря 2015).

10 John Vandiver, "SACEUR: Allies Must Prepare for 'Hybrid Warfare,'” Stars and Stripes, 4 September 2015, www.stripes.com/news/saceur-allies-must-prepare-for-russiahybrid-war-1.301464 (по состоянию на 7 декабря 2015).

11 Peter Pomerantsev, "How Russia Is Revolutionizing Information Warfare," Defense One, 9 September 2014, http://www.defenseone.com/threats/2014/09/how-russiarevolutionizing-information-warfare/93635 (по состоянию на 10 декабря 2015). 
ления», спорной теории, появившейся в 1990-х. ${ }^{12}$ Ключевой концепцией для войны четвертого поколения является использование новых информационных технологий, которые позволяют негосударственным военным акторам подрывать волю государств бороться с ними, целенаправленно воздействуя на факторы, принимающие решения, и на общественность посредством глобальных сетевых СМИ и Интернета. Таким образом, понятие «война» расширяется, охватывая социальные, правовые, психологические и моральные измерения, с которыми военная сила связана в меньшей степени.

Последние определения гибридной войны подобны тем, что имеют место в китайской теории неограниченной войны. Эта концепция всесторонне обсуждается в книге Неограниченная война, которая была опубликована в 1999 году двумя полковниками из Народной освободительной армии (HОA). ${ }^{13}$ В ней предлагаются методы войны, которые позволят странам как Китай противостоять таким оппонентам, располагающим превосходящими военными технологиями, как США. Подобно концепции гибридной войны, неограниченная война подразумевает использование множества средств, как военных, так и невоенных, для нанесения врагу ударов в спину во время конфликта. В одном интервью один из авторов заявил, что «первым правилом неограниченной войны является то, что нет никаких правил, нет никаких запретов». ${ }^{14}$ Поэтому неограниченная война охватывает такие методы, как компьютерное хакерство, подрыв банковской системы, рынков и оборота денег (финансовая война), терроризм, распространение дезинформации в СМИ и ведение боевых действий в городских условиях. Авторы, Цяо Лян и Ван Сянсуи, утверждают, что развитие информационных технологий и глобализация решительно изменили способы ведения войны, которые в свою очередь вышли из военной сферы и перешли в область «новой концепции вооружений», например, использование компьютерных вирусов во время боевых операций. ${ }^{15}$ Эти новые технологии войны обозначались любопытным именем "детские оружия», но тем не менее их использование остается в духе Клаузевица, т.е. для того, чтобы заставить противника подчиниться воле Китая. Как объясняется в одной цитате из «Неограниченной войны»: «детская война, при которой можно избежать кровопролития, тем не менее остается войной. При ней может и изменя-

12 Tim Benbow, "Talking 'Bout Our Generation? Assessing the Concept of Fourth-Generation Warfare," Comparative Strategy 27:2 (2008): 148-163. Еще более спорной является концепция о "войне четвертого поколения» - см. например Donald J. Reed, "Beyond the War on Terror: Into the Fifth Generation of War and Conflict," Studies in Conflict and Terrorism 31:8 (2008): 684-722.

13 Qiao Liang and Wang Xiangsui, Unrestricted Warfare (Beijing: PLA Literature and Arts Publishing House, 1999), 2, https://www.oodaloop.com/documents/unrestricted.pdf (по состоянию на 15 декабря 2015).

14 Там же, 2.

15 Там же, 25. 
ется жестокий процесс войны, но никоим образом не меняется сущность войны, т.е. принуждение, а потому невозможно изменить ее жестокие последствия». ${ }^{16}$ В какой степени неограниченная война стала официальной китайской доктриной, пока неясно. Однако, последние доклады дают основание полагать, что эти технологии находят место в китайском подходе «трех войн» к его территориальным претензиям в Восточно-китайском и Южно-китайском морях. ${ }^{17}$

\section{Являются ли невоенные гибридные методы настоящей войной?}

Термин «гибридная война» иногда используется для описания всех войн, которые не являются строго конвенциональными, т.е. которые ведутся между законно конституированными вооруженными силами национальных государств. Поэтому возможно, что термин «гибридная война» слишком неопределен для практического использования аналитиками и лицами, определяющими политику. Как отмечает латвийский аналитик Янис Берзиньш, «Слово 'гибридное' прилипчиво, оно может выражать кучу вещей». ${ }^{18}$

Включение набора невоенных значений в определение гибридной войны порождает риск характеризовать нормальное межгосударственное соперничество и нормальные межгосударственные конфликты как войну даже при отсутствия угрозы использования насилия. Реалистическая теория международной политики давно постулирует межгосударственные отношения как отношения соперничества и конфликта. Это среда, в которой суверенные государства, на первом месте заинтересованные в своей собственной безопасности, действуют, преследуя свои национальные интересы, сотрудничая и соперничая между собой, как то нужно для достижения своих целей наилучшим образом. Обычные экономические, дипломатические и информационные меры, используемые в межгосударственном соперничестве, обычно не классифицируются как война, если отсутствует угроза использования или действительное использование силы. Однако, многие из заявлений российского правительства и российских СМИ дают основание предполагать, что Россия думает, что находится в состоянии

16 Там же, 30.

17 Смотри к примеру: John Garnaut, “US Unsettled by China's Three Warfares Strategy: Pentagon Report," The Sydney Morning Herald, 11 April 2014, www.smh.com.au/ federal-politics/political-news/us-unsettled-by-chinas-three-warfares-strategypentagon-report-20140410-36g45.html (по состоянию на 16 декабря 2015); и James R. Holmes, “Exposing China's Provocations," The Diplomat, 28 August 2014, http://thediplomat.com/2014/08/exposing-chinas-provocations (по состоянию на 16 декабря 2015).

18

Jānis Bērziṇš, “A New Generation of Warfare," Per Concordiam 6:3 (2015): 24, http://www.marshallcenter.org/mcpublicweb/MCDocs/files/College/F_Publications/ perConcordiam/pC_V6N3_en.pdf (по состоянию на 9 декабря 2015). 
«войны» с западной демократией, культурой и ценностями. ${ }^{19}$ Такое развитие событий дает основание полагать, что по крайней мере в обозримом будущем Россия вернулась к характерной для советской эпохи битве идей с Западом, при которой, перефразируя Клаузевица, мир есть продолжение войны другими средствами. Род Торнтон высказал предположение, что Запад должен приспособиться к ситуации, в которой он находится в «перманентном» состоянии гибридной войны с Россией. ${ }^{20}$ Однако, война в этом контексте является предположительно статус-кво международной политики, и принимать более широкие цели и методы России как форму войны было бы вводящим в заблуждение и потенциально опасным. Аналитик Ральф Тиле, к примеру, включает инвестиции России в ключевые отрасли европейской экономики и связи российской организованной преступности с местными криминальными элементами в российскую модель гибридной войны. $^{21}$ По мнению этого автора, только тогда, когда невоенные методы скоординированы или интегрированы с реальной угрозой использования или с использованием вооруженной силы, политики могут характеризовать международное политическое соперничество как форму гибридной войны. Естественно, ответ на реальную угрозу гибридной войны потребовал бы комплексных, или «касающихся всего государства» мер, поскольку реакция на неконвенциональные методы войны не может основываться только на военных средствах. Вероятно было бы натяжкой классифицировать работу, направленную на идентификацию коррумпированных российских должностных лиц, как форму «войны», хотя это определенно могло бы быть элементом мягкой силы, используемой западными государствами в их соперничестве с Россией Владимира Путина. В целом, стоить помнить, что даже на пике Холодной войны Советский Союз и США могли обуздывать свое соперничество для достижения взаимовыгодных соглашений по контролю за ядерным оружием и для ограничения прокси-войн.

\section{Война нового поколения: российская гибридная война}

Как и авторы Неограниченной войны, российские аналитики не делают секрета из своей цели развивать методы войны, которые смогут противодействовать мощи США, воспринимаемой Россией как высокомерной и угрожающей. Многие российские комментаторы и аналитики утверждают, что Россия находится под ударом постоянной и эффективной информационной кампании США с 1980-х. Такие события, как перестройка и «цветные революции», и такие многосторонние организации, как МВФ и Всемирный банк, воспринимаются как инструменты нерегулярной войны, направлен-

19 "Russia's War on the West," The Economist, 14 February 2015, www.economist.com/ news/leaders/21643189-ukraine-suffers-it-time-recognise-gravity-russian-threatandcounter (по состоянию на 17 декабря 2015).

20 Thornton, "The Changing Nature of Modern Warfare," 45.

21 Thiele, "The Crisis in Ukraine," 6. 
ной на дестабилизацию России. ${ }^{22}$ С российской точки зрения, захват Крыма и операции на Восточной Украине являются стратегическими оборонительными кампаниями для противодействия гибридной войны США против национальных интересов и ценностей России.

Гибридная война - это западное понятие, не российское. Когда по этому вопросу пишут российские аналитики, они используют термины «война нового поколения» и «нелинейная война». Первый из них был представлен западной публике в работе, опубликованной генералом Валерием Герасимовым, Начальником российского генерального штаба, в феврале 2013 года. Поэтому российский подход к гибридной войне иногда не совсем точно называют «Доктриной Герасимова». Герасимов характеризует войну нового поколения как «широкое использование политических, экономических, информационных, гуманитарных и других невоенных средств, ... дополненных гражданскими беспорядками среди местного населения и использованием скрытых вооруженных сил». ${ }^{23}$ Герасимов признает, что многие из методов, упоминаемых им, не являются традиционной частью того, что считается действиями во время войны. Однако, он считает, что они являются типичными методами войны двадцать первого века и на деле имеют большее значение для достижения стратегических целей, чем военные средства, поскольку они могут уменьшить боевой потенциал врага путем инициирования социальных беспорядков и создания климата ощущения распада без открытого использования насилия. ${ }^{24}$ Тем не менее, из работы Герасимова видно, что вооруженные силы имеют существенную дополнительную роль в войне нового поколения. Это, в частности, относится к операциям сил специального назначения (СС), которые могут использоваться под прикрытием «миротворчества или регулирования кризиса» для осуществления связи с оппозиционными группами в целевом государстве. ${ }^{25}$ В своей дискуссии о войнах нового поколения аналитики Сергей Г. Чекинов и Сергей А. Богданов тоже предусматривают использование ССН в «широкомасштабных разведывательных и подрывных миссиях под прикрытием информационных операций». ${ }^{26}$

22 Bērziňš, "A New Generation of Warfare," 23; и Bret Perry, "Non-Linear Warfare in the Ukraine: The Critical Role of Information Operations and Special Operations," Small Wars Journal, 14 August 2015, http://smallwarsjournal.com/jrnl/art/non-linearwarfare-in-ukraine-the-critical-role-of-information-operations-and-special-opera (по состоянию на 9 декабря 2015).

23

Статья генерала Герасимова доступна на английском языке - Mark Galeotti, "The 'Gerasimov Doctrine' and Russian Non-Linear War," In Moscow's Shadows (blog), 6 July 2014, https://inmoscowsshadows.wordpress.com/2014/07/06/the-gerasimovdoctrine-and-russian-non-linear-war (по состоянию на 11 декабря 2015). Там же, 2-3.

25 Там же, 3-4.

${ }^{26}$ Chekinov and Bogdanov, "The Nature and Content of New Generation War," 20. 
Использование ССН под прикрытием информационных операций четко просматривалось на Украине в 2014 году. Формирования спецназа под прикрытием («маленькие зеленые человечки») использовались для захвата государственных зданий и ключевой инфраструктуры и для вооружения сепаратистских милиций, хотя российское государство создавало сомнения и замешательство путем постоянного отрицания российского участия. Другие методы гибридной войны, или войны нового поколения, использовались для деморализации и запугивания противника. В их число входили учения российских конвенциональных сил вблизи границы с Украиной, кибератаки на государственную систему Украины и широкие дипломатические и медиа кампании для подрыва легитимности нового руководства Украины. Конечной целью такой «войны» было оказание психологического давления на целевое государство изнутри таким образом, чтобы политические цели конфликта были достигнуты без военных действий - вершина стратегического искусства согласно Сунь Цзы. Берзиньш точно резюмирует российский подход к современной войне следующим образом:

... основное поле боя находится в уме, и в результате, войны нового по-
коления будут доминироваться информационными и психологическими
способами ведения войны ... Основная цель состоит в уменьшении необ-
ходимости использовать военную силу до возможного минимума, пре-
вращая поддержку военных и гражданского населения противника в ос-
новное оружие для нанесения ущерба руководству и стране.

Многие из методов, которые Россия применила на Украине, восходят к советской эпохе и использованию маскировки, или военной дезинформации. Они были эффективно использованы советскими силами во время Второй мировой войны и в прокси конфликтах во время Холодной войны. К примеру, маскировка использовалась в широком масштабе при операции «Багратион» в 1944 году, когда была уничтожена целая группа армий Германии. На другом конце спектра конфликтов техника маскировки была применена в Восточной Европе, когда советские войска министерства внутренних дел (НКВД) использовали скрытные средства для захвата государственных институций, подрыва гражданского общества и подавления всей оппозиции для навязывания коммунистической власти. ${ }^{28}$ В двадцать первом веке прогресс информационных технологий существенно расширил охват маскировки, позволяя российскому руководству использовать мультимедийную пропаганду и дезинформацию в широком масштабе. Эти методы применялись для обеспечения поддержки внешней политики государства внутри самой России и для ведения широкой «информационной войны»

27 Jānis Bērzinšs, Russian New Generation Warfare in Ukraine: Implications for Latvian Defense Policy (Riga: National Defence Academy of Latvia, 2014), www.naa.mil.Iv/ /media/NAA/AZPC/Publikacijas/PP\%2002-2014.ashx (по состоянию на 14 декабря 2015).

28 Относительно подробного отчета об этом процессе смотри: Anne Applebaum, Iron Curtain: The Crushing of Eastern Europe 1944-1956 (London: Allen Lane, 2012). 
против Украины и Запада. В текущем НАТО контексте Джулиан ЛиндлиФренч определяет маскировку как «войну, которая находится на грани войны, целенаправленную стратегию заблуждения, в которой сочетаются использование силы с дезинформацией и дестабилизацией для создания неопределенности в умах руководителей Альянса относительно того, как следует реагировать». 29

Ключевым элементом маскировки является концепция «рефлексивного контроля» (менеджмента восприятий). ${ }^{30}$ Эта концепция восходит к работе бывшего советского психолога Владимира Лефевра, который разработал эту теорию, когда изучал способы оказания влияния на управление процессом принятия решений противником. Эту теорию можно описать как использование специально подготовленной информации, которая склоняет оппонента к добровольному принятию решения, которое предварительно было определено как желательное инициатором данной информации. В число методов входят шантаж, камуфляж, заблуждение и дезинформация, направленные на вмешательство в цикл принятия решений оппонента, которое привело бы к благоприятной для России политике. Продолжающийся постсоветский интерес к технологиям рефлексивного контроля был продемонстрирован началом выпуска нового журнала по вопросам безопасности, озаглавленного Рефлексивные процессы и управление, не далее, как в 2001 году. $^{31}$

На практике, осуществление войны нового поколения поднимает существенные проблемы. Для достижения конечных военных и политических целей приходится координировать, интегрировать и контролировать широкий спектр участников - гражданских и военных, регулярных и нерегулярных, а также их действия. Особенно трудным является единое политическое управление, так как нерегулярные и государственные акторы часто имеют разные политические интересы. Даже для такой авторитарной страны как Россия, управление и координация оказались трудными во время операций на Украине, которые, похоже, скоординированы в гораздо меньшей степени, чем думали западные комментаторы в то время. ${ }^{32} \mathrm{~K}$ примеру, в одном анализе Центра имени Вильсона делается вывод, что рос-

29 Julian Lindley-French, NATO: Countering Strategic Maskirovka (Calgary: Canadian Defence and Foreign Affairs Institute, 2015), 4, http://www.cgai.ca/nato_countering_ strategic_maskirovka (по состоянию на 8 декабря 2015).

30 Timothy L. Thomas, "Russia's Reflexive Control Theory and the Military," Journal of Slavic Military Studies 17 (2004): 237-256; и Maria Snegovaya, Putin's Information Warfare in Ukraine: Soviet Origins of Russia's Hybrid Warfare (Washington, DC: Institute for the Study of War, 2015), http://understandingwar.org/sites/default/files/ Russian\%20Report\%201\%20Putin\%27s\%20Information\%20Warfare\%20in\%20Ukraine -\%20Soviet\%20Origins\%20of\%20Russias\%20Hybrid\%20Warfare.pdf (по состоянию на 11 декабря 2015).

31 Thomas, "Russia's Reflexive Control Theory and the Military," 237.

32 Freedman, "Ukraine and the Art of Limited War," 11; Kofman and Rojansky, "A Closer Look at Russia's Hybrid War," 5. 
сийские действия на Украине не были частью хорошо скоординированной главной стратегии, а скорее, отражали «непланированную последовательность попыток подбирать разные инструменты для разных - часто неожиданных - оперативных реалий». ${ }^{33}$

\section{Российская гибридная война как угроза для НАТО}

Много опасений было высказано об уязвимости НАТО в отношении российских технологий гибридной войны. Естественно, безопасность прибалтийских государств с их значительными русскоговорящими меньшинствами является предметом особой озабоченности. Россия давно проводит политику ослабления, разделения и, в конечном итоге, нейтрализации НАТО. Балтийские государства дают Путину потенциальный рычаг для достижения этой цели. Совершенно также, как российское вмешательство в дела Украины началось задолго до аннексии Крыма, постоянно увеличивается политическое и социальное давление на Балтийские государства. ${ }^{34}$ Некоторые европейские разведывательные агентства так же выразили опасения касательно Болгарии, для которой считается, что вся политическая система компрометирована криминальными организациями, связанными с российским государством через российские разведывательные агентства. ${ }^{35}$ Стратегия НАТО для борьбы с российской гибридной угрозой требует сочетания дипломатических, военных, информационных, экономических и правоохранительных мер. Причем такой комплексный подход должен быть соответственно интегрированным, а не просто привлекать к участию гражданские ведомства для оказания поддержки вооруженным силам или для замены вооруженных сил гражданскими структурами из-за нежелания применять силу.

В случае кризиса с участием балтийских государств Россия, вероятно, попытается разделить членов НАТО, оставаясь ниже очевидного порога Статьи 5, по крайней мере в начале. Как и в украинском кризисе 2014 года, дезинформация, запугивание и пропаганда будут использоваться для склонения менее устойчивых членов НАТО к российской точке зрения на события, что соответственно укрепит их существующий настрой на избежание военной реакции. Дезинформация будет использоваться против руководств НАТО и широкого общественного мнения для выведения Альянса из политического и военного равновесия. Запугивание, вероятно, будет состоять в подчеркивании очевидной готовности России использовать ядерное

33 Kofman and Rojansky, "A Closer Look at Russia's Hybrid War," 5.

34 Смотри, к примеру Andrew Osborn, "Putin a Threat to Baltic States, Western Officials Say," Reuters, 19 February 2015, http://uk.reuters.com/article/uk-britainrussia-baltics-idUKKBNOLNOFT20150219 (по состоянию на 18 декабря 2015).

35 Sam Jones, "Ukraine: Russia's New Art of War," Financial Times, 28 August 2014, http://www.ft.com/intl/cms/s/2/ea5e82fa-2e0c-11e4-b760-00144feabdc0.html (по состоянию на 10 декабря 2015). 
оружие для деэскалации «агрессии» НАТО. Эффективная стратегическая коммуникация могла бы противостоять российским дискурсам, но она должна быть более чуткой, когерентной и последовательной. Хотя ЕС принял план действий по стратегической коммуникации на 2015 год, нет никаких признаков, что процесс планирования ЕС включает координацию с ЦПК СТРАTKOМ НАТО, который был учрежден в 2014 году. ${ }^{36}$ Такая координация была бы жизненно важной для эффективной реакции на российскую дезинформационную и пропагандистскую кампанию. К несчастью, В этом плане авторитарные общества располагают преимуществом, поскольку им легче мобилизовать все ресурсы государства для достижения политических целей, не считаясь с ограничениями, накладываемыми децентрализованным распределением власти и демократическим процессом формирования консенсуса. У либеральных демократий, наоборот, наблюдается неприязнь к пропаганде и психологической войне, и союзу НАТО будет трудно согласовать содержание и способы ведения стратегической коммуникационной кампании. Как подтверждает ЦПК СТРАТКОМ, Россия располагает потенциальным асимметричным преимуществом перед Западом, поскольку свободные СМИ Запада не могут соперничать с централизованными и синхронизированными российскими информационными операциями. ${ }^{37}$

Однако, НАТО может оказаться не настолько уязвимым в отношении информационной войны, как многие сейчас считают. Пропаганда может иметь особенно сильное влияние, когда у населения, как в России, нет альтернативных источников информации, но везде в других местах пропаганда должна быть достаточно правдоподобной, чтобы формировать убеждения и чувства и чтобы использовать неуверенность, недоверие и паранойю. Заявления российского руководства и российские медиа источники становятся все более дискредитированными на Западе, особенно после их реакции на то, как был сбит самолет, выполнявший полет МН 17 над Украиной в июле 2014 года. Усиленный контроль над национальными СМИ и Интернетом, а также преследование инакомыслящих дают возможность формировать российское общественное мнение. Однако, несмотря на попытки Russia Today (RT) и настоящей армии интернет троллей противоречить и обижать новостные порталы и социальные медиа, которые занимают антироссийские позиции, российские информационные операции в целом не успели оказать влияние на не-русскоговорящую публику. ${ }^{38}$ Украинские правительственные источники заявляют, что наблюдается очень низкий уро-

36 Bastian Giegerich, "Hybrid Attacks Demand Comprehensive Defence," Ethics and Armed Forces 2 (2015): 15, http://www.ethikundmilitaer.de/fileadmin/Journale/ 2015-12_English/Hybrid_Warfare-Enemies_at_a_Loss_2015-2.pdf (по состоянию на 9 декабря 2015).

37 StratCom COE, Analysis of Russia's Information Campaign Against Ukraine, 3.

38 Freedman, "Ukraine and the Art of Limited War," 23; и Snegovaya, "Putin's Information Warfare in Ukraine," 18-20. 
вень общественного доверия к любому официальному российскому СМИ, ${ }^{39}$ и несмотря на интенсивную российскую информационную кампанию, поддержка прорусских сепаратистов даже среди русскоговорящих граждан Украины ниже, чем можно было ожидать. Это в какой-то мере объясняет более открытое участие России в конфликте летом 2014 года. ${ }^{40}$

Во время кризиса российская тактика, вероятно, будет включать скрытую поддержку местных пророссийских активистов. Как и на Украине, неуверенность и невозможность доказать участие будут затруднять подтверждение факта проводившегося нападения. Следующая цитата Марка Галеоти особенно ярко иллюстрирует потенциальные трудности реакции на такие методы:

Первым маленьким зеленым человечном, в конце концов, может быть 15-
летняя русская эстонская девочка, размахивающая плакат со словами «У
русскоговорящих тоже есть права!» на границе города Нарва. Застрелить ее?
Конечно, нет. Вторым может быть ее старший брат, кидающий камни в
полицейских, пришедших арестовать ее. Застрелить его? Будем надеяться,
что нет, особенно поскольку можно быть полностью уверенным, что запись
этого инцидента незамедлительно будет запущена по всем российским ТВ
каналам. ${ }^{11}$

Паравоенная полиция, вероятно, была бы лучше оборудованной и подготовленной, чем солдаты для таких ситуаций, что является еще одним примером того, когда тесное сотрудничество между ЕС и НАТО несомненно было бы взаимовыгодным.

Если кризис начнет разрастаться, Россия может поддаться искушению захватить территорию уязвимых фронтовых держав открыто военными средствами до того, как Альянс организует эффективный коллективный ответ. ${ }^{42}$ Кошмарным для НАТО сценарием была бы оккупация части государства-члена, даже если это временно. Такое действие вынудит Альянс применить статью 5 Вашингтонского договора и подвергнуться риску прямой вооруженной конфронтации с ядерной Россией или не среагировать на агрессию и подвергнуться риску краха НАТО в качестве жизнеспособного военного союза. Несмотря на опасения таких государств, как Германия, эффективное сдерживание потребует постоянной дислокации значительных многонациональных сил на территории государств, которые находятся в рисковой ситуации, для того, чтобы не дать возможность России сделать

39 "Sociology of Information Warfare in Ukraine," Europe Insight, 11 October 2015, http://en.europeinsight.net/sociology-of-information-warfare-in-ukraine (по состоянию на 10 декабря 2015).

40 Kofman and Rojansky, "A Closer Look at Russia's Hybrid War," 5.

41 Mark Galeotti, "Time to Think About Hybrid Defense," War on the Rocks, 30 July 2015, http://warontherocks.com/2015/07/time-to-think-about-hybrid-defense (по состоянию на 8 декабря 2015).

42 Смотри Elbridge Colby and Jonathan Solomon, "Facing Russia: Conventional Defence and Deterrence in Europe," Survival 57:6 (2015): 23-24. 
военное решение свершившимся фактом. Хотя Объединенная оперативная группа войск высокой степени готовности (ООГВ) численностью в 5000 человек должна быть в состоянии развернуться очень быстро, она все же может опоздать для предотвращения российского авантюризма. Российский подход к гибридной войне не исключает прямое использование военной силы, когда это необходимо. Летом 2014 года, когда Россия исчерпала свой запас невоенных гибридных методов, военные операции на Украине приняли характер ограниченной конвенциональной войны. Российские батальонные тактические группы (БТГ) вмешивались напрямую в бои против украинской армии. Военные действия включали столкновения между бронетанковыми силами, интенсивные городские бои пехоты, барражный огонь тяжелой артиллерии и, по крайней мере с российской стороны, использование БЛА для наблюдения и целеуказания, электронную войну и использование средств ПВО. ${ }^{43}$ Войска НАТО начали уже усваивать уроки украинских военных, касающиеся российской тактики и технологии, в частности использование БЛА для наведения огня артиллерии и использование российских электронных средств подавления. ${ }^{44}$ Однако, только тактические усовершенствования вряд ли будут достаточны для обеспечения надежного конвенционального сдерживания против вооруженного нападения.

\section{Заключение}

Гибридные методы ведения войны не меняют сущность войны. Насилие остается основой гибридной войны, как и при любой другой форме войны, и их цель та же самая, как и при любом другом акте войны, а именно, использовать угрозу применения или применение организованного насилия для получения физических или психологических преимуществ перед противником. Однако, изобилие терминологии - гибридная, асимметричная, неконвенциональная, нелинейная, нового поколения, четвертого и пятого поколения, серая и т.д. война - отражает трудности, с которыми продолжают сталкиваться стратеги и теоретики при классификации сложных вооруженных конфликтов двадцать первого века. Хотя термин «гибридная» на данный момент является самим популярным, он никоим образом не является единственным для описания этих войн. Факт, что при многих вооруженных конфликтах размывается грань между войной и миром и используются инструменты, которые традиционно не являются частью военных действий, еще больше усложняет эту проблему. Это, несомненно, является вызовом для традиционного истеблишмента из сектора безопасно-

43 Philip A. Karber, Lessons Learned from the Russo-Ukrainian War (Vienna, VA: The Potomac Foundation, 2015).

44 "Situation Report," Foreign Policy, 10 December 2015, http://foreignpolicy.com/ 2015/12/10/situation-report-carter-gets-through-another-hill-appearance-new-bookby-former-intel-chief-nato-training-against-russian-tactics-india-comes-to-thepentagon-house-wants-to-supply-kurds-new-nort (по состоянию на 14 декабря 2015). 
сти, который должен рассматривать широкий круг угроз, идентифицированных аналитиками и теоретиками гибридной войны. Если раскинуть сеть определения слишком широко, термин гибридная война становится слишком всеохватным для практического использования политиками. Если дать слишком узкое определение, люди, определяющие политику, не смогут осознать значение многих нетрадиционных технологий, которые используются противником, как прелюдию или дополнение к применению военной силы.

Независимо от того, каким ярлыком обозначена угроза, стратеги должны решать, как наилучшим образом справляться с методами, применяемыми противником, кем бы он ни был - государственным или негосударственным актором. Иногда наиболее подходящая ответная реакция может включать применение специфических политических, информационных, экономических, дипломатических, или в случае физической угрозы, военных средств государственности. Более сложные угрозы требуют целостного государственного или комплексного подхода. Обычно наилучшая стратегия включает координацию и направление всех эффективных инструментов государственной мощи, независимо от того, каким образом определена угроза. Несомненно, НАТО нужно расширять свои военные способности для сдерживания, но в случае отношений соперничества между Западом и Россией Путина, искушение характеризовать эту конкуренцию как гибридная война может взорвать уже непростую ситуацию в сфере безопасности и застить глаза государственным руководствам на потенциально продуктивные традиционные инициативы дипломатической политики.

\section{Об авторе}

Профессор Уизер является отставным британским офицером и бывшим исследователем истории военных действий $20^{- \text {го }}$ века Имперского военного музея в Лондоне. Он преподавал терроризм, способы военных действий и связанные с безопасностью предметы в разных институциях, в том числе в Академии ФБР, Школе НАТО, Центре профессиональной квалификации НАТО по Защите против терроризма (ЦПК-ЗПТ), Женевском центре политики безопасности и в разных штабных колледжах и военных университетах в Европе и Евразии. E-mail: witherj@marshallcenter.org. 